\title{
Acute Renal Failure in Systemic Lupus Erythematosus
}

\author{
C. PONTICELLI, \\ E. IMBASCIATI, \\ D. BRANCACCIO, \\ A. TARANTINO, \\ E. RIVOLTA
}

British Medical fournal, 1974, 3, 716-719

\begin{abstract}
Summary
Acute anuric renal failure complicating systemic lupus erythematosus does not usually respond to treatment with corticosteroids and immunosuppressive agents. We describe four cases treated by dialysis, corticosteroids, and heparin in anticoagulant doses in which there was remarkable improvement in renal function after prolonged anuria. One patient died later from a gastric haemorrhage. The other three were alive and well 55, 54, and 30 months from the onset of anuria. In two cases a second renal biopsy showed a striking improvement in the lesions. Large doses of corticosteroid and heparin may be the best treatment in acute anuric lupus nephritis.
\end{abstract}

\section{Introduction}

Acute renal failure occurs in less than $4 \%$ of cases of systemic lupus erythematosus and is associated with severe renal lesions (Muehrcke, 1969). The prognosis is generally bad. Most patients die within a few weeks despite high doses of corticosteroids and immunosuppressive drugs (Baldwin et al., 1970; Cameron et al., 1970; Zech et al., 1972). In this paper we describe four cases of acute anuric lupus nephritis. All were treated with dialysis, corticosteroids, and heparin and all recovered renal function after prolonged anuria. One patient died after a few weeks from sepsis and gastric haemorrhage. The other three are alive and well.

\section{Patients and Methods}

All four patients were women. In all of them a lupus erythematosus cell preparation was positive, and the test for antinuclear factors (A.N.F.) gave a strongly positive reaction with a diffuse pattern. They all suffered prolonged anuria and required dialysis. They were all treated with prednisone in doses exceeding $1 \mathrm{mg} / \mathrm{kg}$ for periods varying with individual tolerance. Heparin was given subcutaneously twice daily in doses sufficient to maintain the whole-blood clotting time within 15 to 20 minutes for a period of 12 hours.

Kidney tissue specimens obtained percutaneously for biopsy were fixed in Dubosq-Brazil and sections 2 to $3 \mu$ in thickness were stained with hematoxylin and eosin, periodic acid Schiff, Masson's trichrome, and silver methenamine. In three cases a second portion of tissue was obtained for immunohistological studies. The fragment was frozen in isopentane cooled with acetone and dry ice. Sections $4 \mu$ in thickness cut in cryostat were incubated with antisera prepared in the rabbit and directed against human albumin, IgG, IgA, IgD, IgM, IgE, C3, CA, fibrinogen, and $\beta$-lipoproteins.

\footnotetext{
Nephrology and Dialysis Unit, Polyclinic Hospital of Milan, 20122 Milan, Italy

C. PONTICELLI, M.D., First Assistant in Nephrology

E. IMBASCIATI, M.D., Assistant in Nephrology

D. BRANCACCIO, M.D., Assistant in Nephrology

D. BRANCACCIO, M.D., Assistant in Nephrology
A. TARANTINO, M.D., Assistant in Nephrology

A. TARANTINO, M.D., Assistant in Nephrol
}

All antisera gave single precipitin arcs when tested by immunoelectrophoresis. Most antisera were conjugated with fluorescein isothiocyanate by a single layering technique. With IgE, IgD, and $\mathrm{CA}$ a double layering technique was used. The tissue was first incubated with an unconjugated rabbit antiserum and then with a fluorescein-isothiocyanateconjugated goat anti-rabbit globulin serum.

\section{Case 1}

A 33-year-old biparous woman had a normal delivery on 21 April 1969 after a pregnancy complicated by proteinuria. After a few days haematuria and oedema developed. On 3 May she was admitted to our renal unit with signs of renal failure (table I) which laboratory investigations (table II) confirmed. Renal biopsy (fig. 1) showed diffuse intracapillary proliferation and epithelial proliferation in one-fifth of the glomeruli. The capillary walls were irregularly thickened, fibrin thrombi occluded glomerular capillaries, and polymorphonuclear leucocytes and nuclear fragments were present between the loops. Despite treatment with

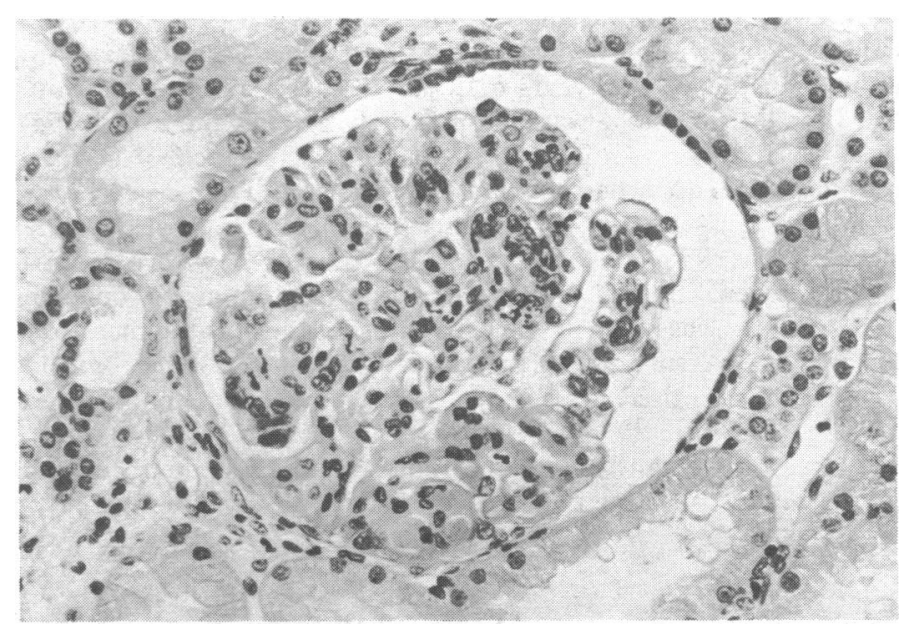

FIG. 1-Case 1. First renal biopsy: intracapillary proliferation and fibrinoid thrombi in capillary loops.

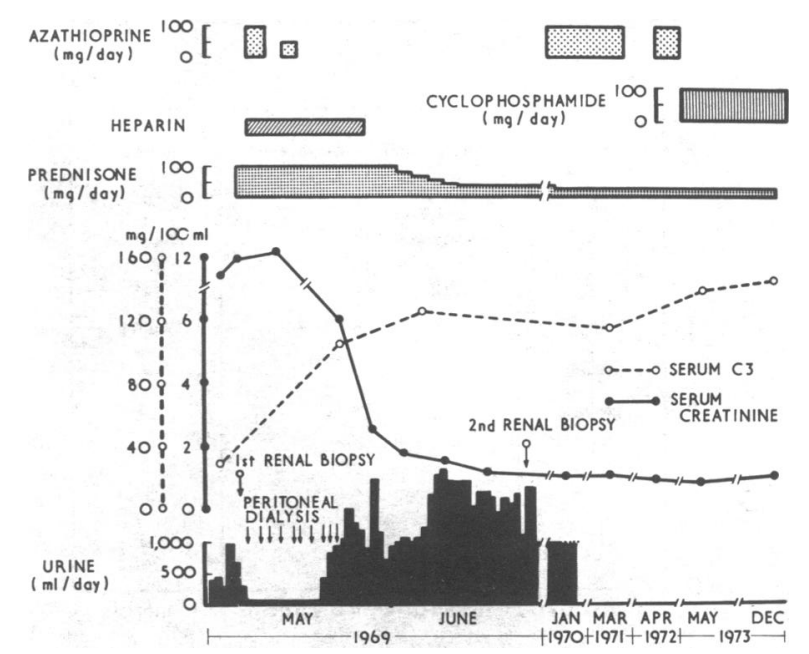

FIG. 2-Case 1. Clinical course. 
TABLE I-Clinical Findings in Four Patients on Admission to Renal Unit

\begin{tabular}{|c|c|c|c|c|c|c|c|c|c|}
\hline Case No. & Fever & Oedema & Arthralgia & $\begin{array}{l}\text { Blood Pressure } \\
(\mathrm{mm} \mathrm{Hg})\end{array}$ & Erythema & $\begin{array}{c}\text { Haemorrhagic } \\
\text { Diathesis }\end{array}$ & $\begin{array}{c}\text { Neurological } \\
\text { Signs }\end{array}$ & $\begin{array}{c}\text { Hepato- } \\
\text { splenomegaly }\end{array}$ & Serositis \\
\hline $\begin{array}{l}1 \\
2 \\
3 \\
4\end{array}$ & $\begin{array}{l}- \\
+ \\
+ \\
+\end{array}$ & $\begin{array}{l}+ \\
+ \\
+ \\
+\end{array}$ & $\begin{array}{l}\overline{-} \\
\bar{t}\end{array}$ & $\begin{array}{l}130 / 80 \\
150 / 100 \\
205 / 120 \\
160 / 100\end{array}$ & $\begin{array}{l}\bar{z} \\
\bar{t}\end{array}$ & $\begin{array}{l}\overline{+} \\
-\end{array}$ & $\begin{array}{l}+ \\
+ \\
+ \\
+\end{array}$ & $\begin{array}{l}+ \\
+ \\
+\end{array}$ & $\begin{array}{l}- \\
+ \\
+ \\
+\end{array}$ \\
\hline
\end{tabular}

TABLE II-Laboratory Findings in Four Patients on Admission to Renal Unit

\begin{tabular}{|c|c|c|c|c|c|c|c|c|c|}
\hline Case No. & $\begin{array}{l}\text { Blood Urea } \\
(\mathrm{mg} / 100 \mathrm{ml})\end{array}$ & $\underset{\text { Creatinine }}{\text { Serum }}$ & $\stackrel{\mathrm{C3}}{(\mathrm{mg} / 100 \mathrm{ml})}$ & $\stackrel{\text { A.N.F. }}{(\geqslant 1 / 100)}$ & $\begin{array}{l}\text { L.E. } \\
\text { Cells }\end{array}$ & $\begin{array}{l}\text { Rheumatoid } \\
\text { Factor }\end{array}$ & $\begin{array}{l}\text { Platelets } \\
/ \mathrm{mm}^{3}\end{array}$ & $\begin{array}{l}\text { Serum } \alpha \text {-Glob- } \\
\text { ulin (\% Total } \\
\quad \text { Protein) }\end{array}$ & $\begin{array}{l}\text { W.B.C. } \\
/ \mathrm{mm}^{3}\end{array}$ \\
\hline $\begin{array}{l}1 \\
2 \\
3 \\
4\end{array}$ & $\begin{array}{l}280 \\
160 \\
210 \\
390\end{array}$ & $\begin{array}{r}11.5 \\
5.2 \\
7.1 \\
13.5\end{array}$ & $\begin{array}{l}25 \\
26 \\
61 \\
40\end{array}$ & $\begin{array}{l}+ \\
+ \\
+ \\
+\end{array}$ & $\begin{array}{l}+ \\
+ \\
+ \\
+\end{array}$ & $\begin{array}{l}- \\
+ \\
+\end{array}$ & $\begin{array}{r}125,000 \\
80,000 \\
160,000 \\
366,000\end{array}$ & $\begin{array}{l}33 \\
30 \\
55 \\
39\end{array}$ & $\begin{array}{r}5,000 \\
4,200 \\
3,000 \\
15,000\end{array}$ \\
\hline
\end{tabular}

prednisone $100 \mathrm{mg} /$ day the patient became anuric (fig. 2). Peritoneal dialysis, subcutaneous heparin in anticoagulant doses, and azathioprine by mouth were immediately started. Azathioprine was stopped after three days because of a leucopenia. After 15 days of anuria the renal function progressively improved. In June 1969 a second renal biopsy (fig. 3) showed a moderate mesangial proliferation without any other abnormalities. The patient continued treatment with low doses of prednisone until April 1972, when she was started on cyolophosphamide. When last seen in December 1973 investigations showed serum creatinine $1.1 \mathrm{mg} / 100 \mathrm{ml}$, blood urea $20 \mathrm{mg} / 100 \mathrm{ml}$, A.N.F. present (dilution 1/100), and proteinuria $3 \mathrm{~g} / 24 \mathrm{hr}$.

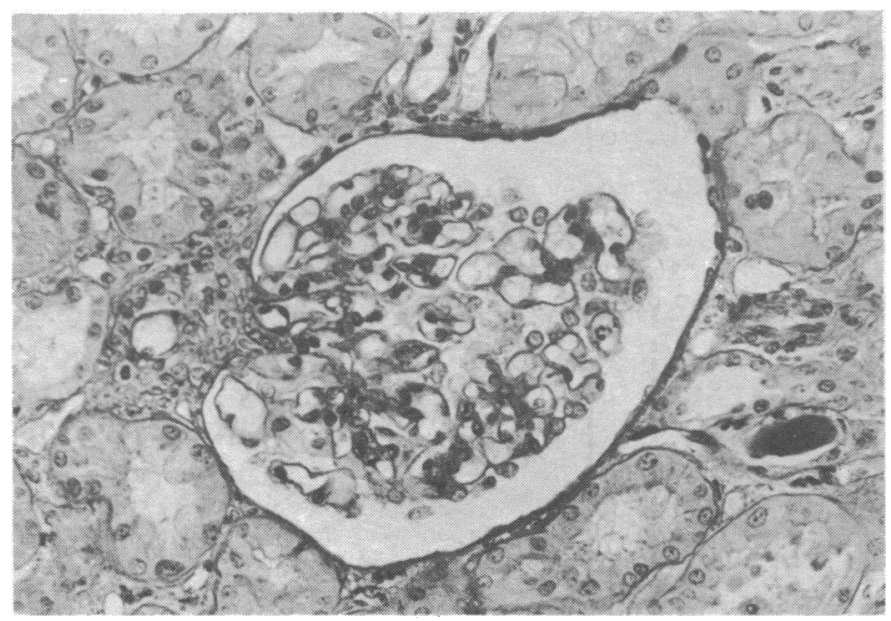

FIG. 3-Case 1. Second renal biopsy: striking improvement in glomerular lesions.

\section{Case 2}

A 38-year-old woman gave birth to a normal child in February 1969 after a pregnancy complicated by proteinuria, oedema, and arterial hypertension. In the following July she was admitted to our unit with renal failure, fever, severe anaemia, and skin purpura (table I and II). Renal biopsy (fig. 4) showed moderate intracapillary proliferation and epithelial crescents in one quarter of the glomeruli, subendathelial fibrinoid necrosis of arteriolar walls, and thrombosis of small vessels. The patient became anuric. Treatment with prednisone $1 \mathrm{mg} / \mathrm{kg}$, heparin in anticoagulant doses, and peritoneal dialysis was started (fig. 5). During the anuric period the patient had two episodes of convulsions, not apparently due to water or electrolyte imbalance. After $\mathbf{3 0}$ days renal function progressively improved. Biopsy in September showed no intraglomerular fibrinoid deposits or arteriolar thrombosis but a moderate intracapillary proliferation remained. No deposits were seen by immunofluorescence. Anticaagulant therapy was continued and azathioprine was added. In September 1970 a

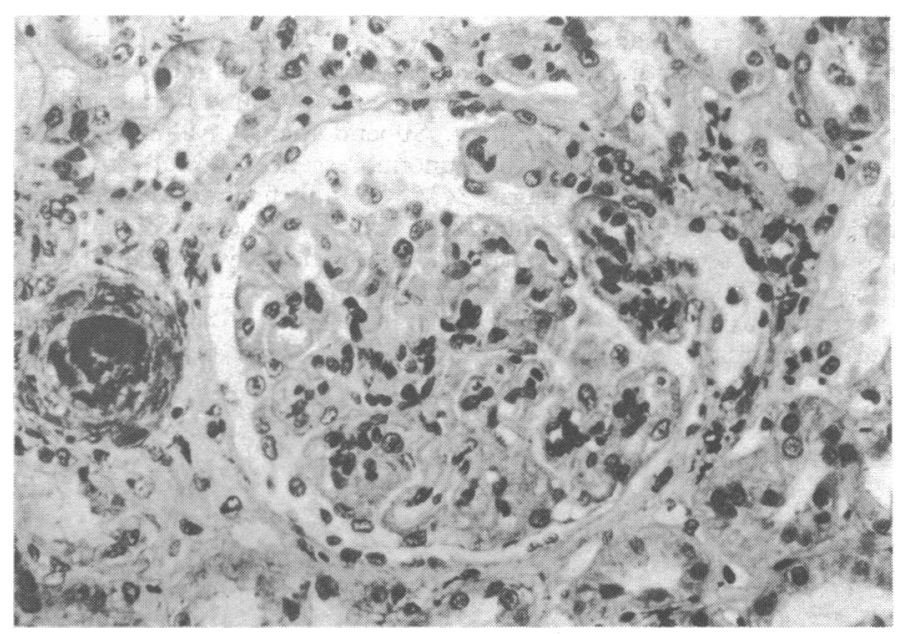

pIG. 4-Case 2. First renal biopsy: fibrinoid necrosis and thrombotic occlusion of arterioles.

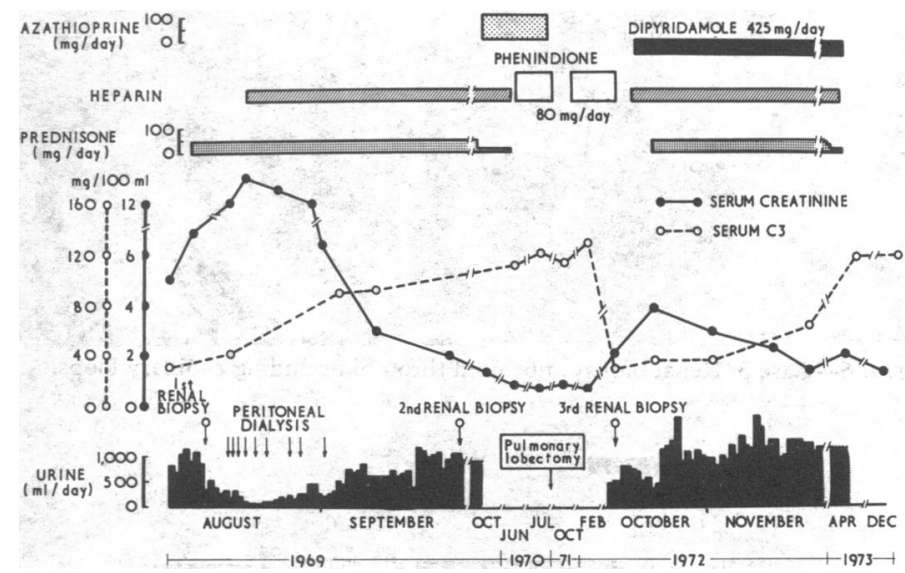

FIG. 5-Case 2. Clinical course.

right pulmonary lobectomy was performed for a tuberculous granuloma. Investigations at that time showed serum creatinine $0.9 \mathrm{mg} / 100 \mathrm{ml}$, blood urea $35 \mathrm{mg} / 100 \mathrm{ml}$, proteinuria $0.4 \mathrm{~g} / 24 \mathrm{hr}$, C3 $1.30 \mathrm{mg} / 100 \mathrm{ml}$, and no A.N.F. The anticoagulant and immunosuppressive therapy was replaced by streptomycin, isoniazid, and, later, ethambutol and rifampicin. Renal function remained within normal range and the proteinuria disappeared. There were no signs of lupus.

In September 1972 the patient was readmitted because of asthenia, anorexia, and oedema. The findings on investigation were: serum creatinine $2.7 \mathrm{mg} / 100 \mathrm{ml}$, blood urea $110 \mathrm{mg} / 100$ 
$\mathrm{ml}$, C3 $35 \mathrm{mg} / 100 \mathrm{ml}$, A.N.F. present $(1 / 100)$, W.B.C. $2,300 / \mathrm{mm}^{3}$, R.B.C. $3,000,000 / \mathrm{mm}^{3}$, platelets $200,000 / \mathrm{mm}^{3}$. Biopsy showed severe intracapillary proliferation, fibrinoid deposits in the loops, and thrombotic obstruction of the capillary lumina. Immunofluorescence showed granular and coarse deposits on the glomeruli of IgG, IgA, IgM, IgE, IgD, C3, and fibrinogen. Treatment with prednisone, subcutaneous heparin, dipyridamole, and cyclophosphamide improved the clinical picture. She was discharged on a regimen of cyclophosphamide $(1 \mathrm{mg} / \mathrm{kg} /$ day), heparin 250 $\mathrm{mg} /$ day subcutaneously, and dipyridamole $425 \mathrm{mg} /$ day by mouth. When last seen in December 1973 the findings were: blood pressure $150 / 100 \mathrm{~mm} \mathrm{Hg}$, serum creatinine $1.6 \mathrm{mg} / 100 \mathrm{ml}$, blood urea $40 \mathrm{mg} / 100 \mathrm{ml}, \mathrm{C} 3110 \mathrm{mg} / 100 \mathrm{ml}$, no A.N.F., and proteinuria $0 \cdot 1 \mathrm{~g} / 24 \mathrm{hr}$.

\section{Case 3}

A 45-year-old woman was successfully treated with corticosteroids for dermatomyositis in 1966. In May 1971 she was admitted tr hospital with oedema, arterial hypertension, and progressive renal failure. She was transferred to our renal unit on 25 June (tables I and II). Renal biopsy (fig. 6) showed several sclerotic glomeruli, other glomeruli with moderate intracapillary proliferation, irregular fibrinoid deposits on the capillary loops, many intracapillary thrombi, and hematoxyphil bodies. Subendothelial hyaline deposits were seen in the arterioles. Immunofluorescence showed irregular deposits of IgD, IgE, IgG, IgA, IgM, C3, and fibrinogen along the basal membranes and oocluding the capillary loops. Similar deposits were seen in the arterioles. The patient was treated with frusemide $800 \mathrm{mg} /$ day, prednisone, cyclophosphamide, and heparin subcutaneously (fig. 7). Her general condition worsened, she became anuric, and peritoneal dialysis was begun. Cyclo-

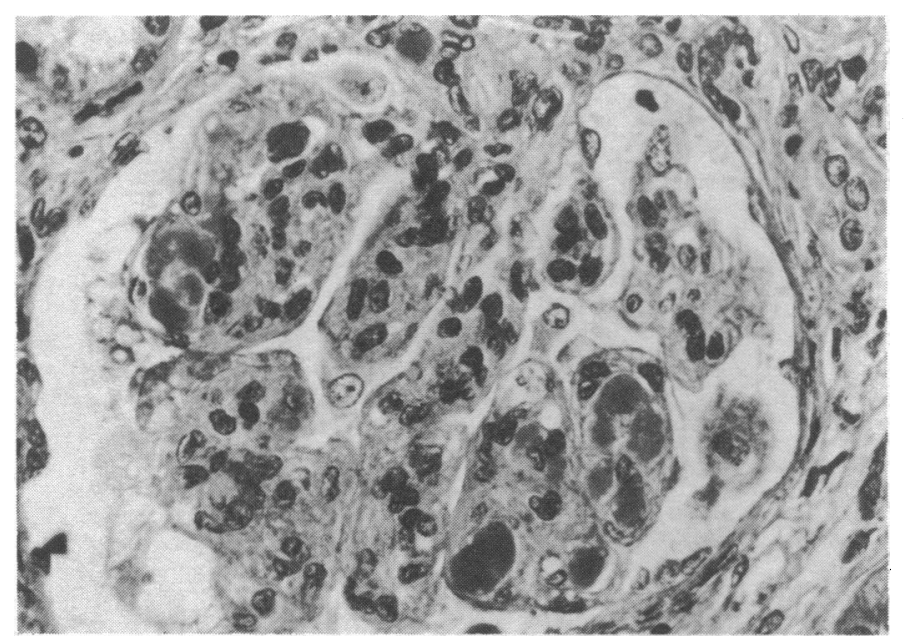

FIG. 6-Case 3. Renal biopsy: fibrinoid thrombi occluding capillary loops.

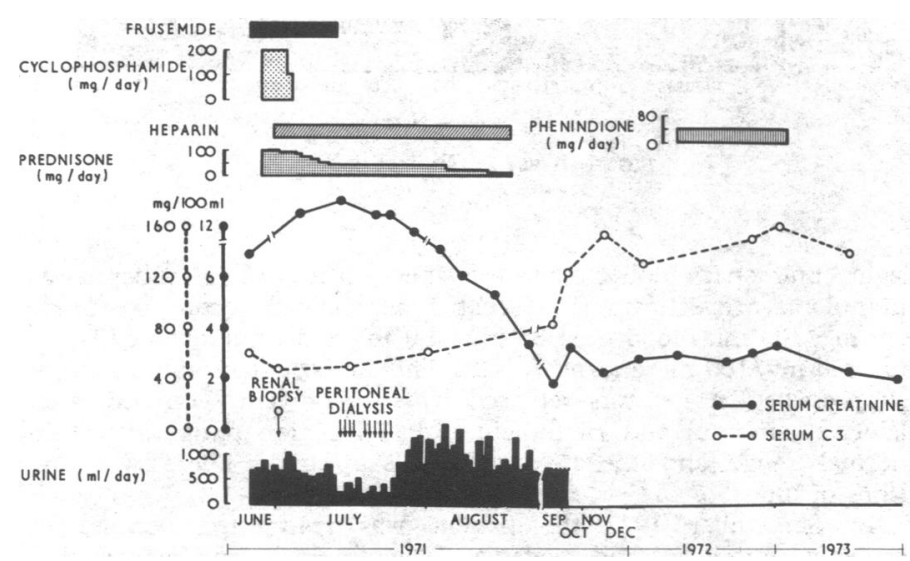

FIG. 7-Case 3. Clinical course. phosphamide was stopped after a few days owing to severe anaemia and leucopenia. After 12 days of oliguria the patient's renal function slowly recovered. After she was discharged her renal function stabilized at subnormal levels. When last seen in December 1973 the findings were: serum creatinine $2.0 \mathrm{mg} / 100$ $\mathrm{ml}$, C3 $140 \mathrm{mg} / 100 \mathrm{ml}$, no A.N.F., proteinuria $1.4 \mathrm{~g} / 24 \mathrm{hr}$, and blood pressure $160 / 100 \mathrm{~mm} \mathrm{Hg}$.

\section{Case 4}

A 39-year-old woman developed facial and forearm erythema and pains in the small joints in June 1966. In January 1971 she began to suffer from headaches and oedema, and by the end of July she had fever, exacerbations of the arthralgia, and progressive oliguria. On 28 August she was anuric and was admitted to our renal unit (tables I and II). Peritoneal dialysis was immediately started. Light microscopy examination of renal tissue showed diffuse intracapillary proliferation and epithelial crescents in about half the glomeruli, polymorphonuclear infiltration, and haematoxylin bodies. Immunofluorescence showed diffuse granular deposits of IgG, IgA, IgM, IgD, IgE, C3, C4, and fibrinogen on the glomerular loops. She was treated with prednisone, heparin subcutaneously, and azathioprine, which was stopped after a few days because of a leucopenia (fig. 8). After 15 days there was a diuresis. Dialysis was stopped. The patient's renal function gradually improved but not her general condition. She developed a urinary infection and on 2 October she died from a gastric haemorrhage. Permission for necropsy was refused. Investigations the day before she died showed: serum creatinine $1.9 \mathrm{mg} / 100 \mathrm{ml}$, blood urea $84 \mathrm{mg} / 100 \mathrm{ml}$, and proteinuria $2 \cdot 1 \mathrm{~g} / 24 \mathrm{hr}$.

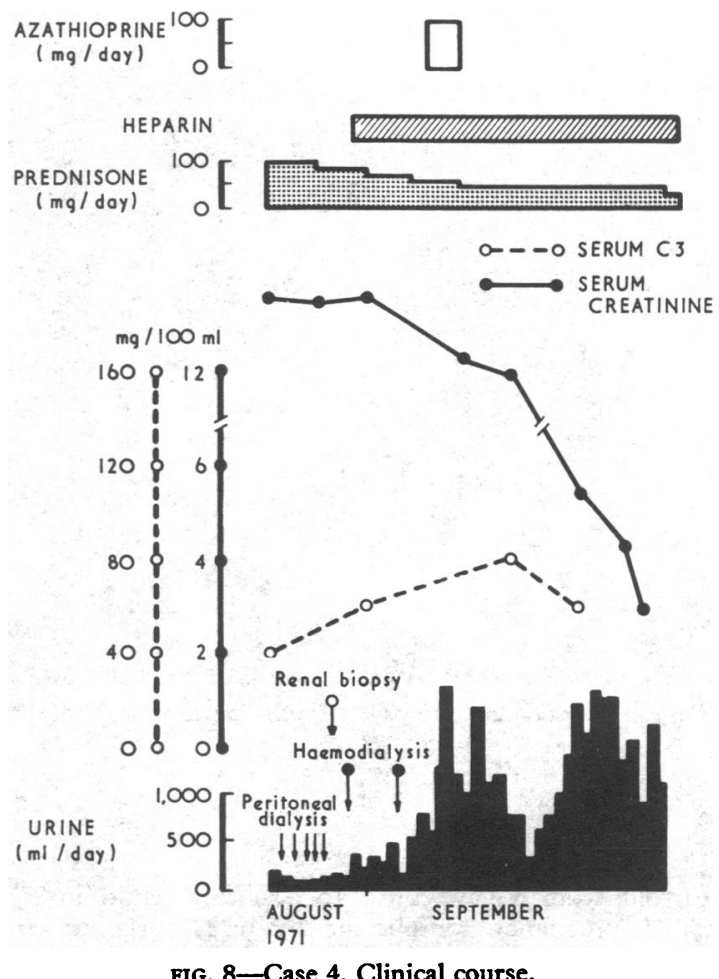

FIG. 8-Case 4. Clinical course.

\section{Discussion}

Renal function improved in all four patients reported on here and three of them were living many months after their acute illness. This does not prove that the outcome was due to treatment, but it certainly shows that patients with severe renal lesions associated with systemic lupus erythematosus may recover.

At present the choice of treatment in cases of acute anuric lupus is speculative. The use of cytostatic agents is contro- 
versial. Their effect is apparent only after several weeks or months (Maher and Schreiner, 1970; Cade et al., 1973) and they are far from safe. We were obliged to stop them in our patients after a few days owing to the onset of leucopenia. Corticosteroid treatment can lead to a striking improvement in the extrarenal symptoms in acute systemic lupus erythematosus (Lange et al., 1965; Dubois, 1966; Christian, 1969; Agnello et al., 1973). Even though it does not by itself seem able to stop the rapid progress of lupus nephritis (Slama et al., 1962; Baldwin et al., 1970; Pollak and Mendoza, 1971; Donadio et al., 1972; Dillard et al., 1973) it may protect the kidney from further lesions by inhibiting the production of circulating antibodies (Bjørneboe et al., 1951; Germuth, 1956) and preventing the deposition of immune complexes in the basement membrane of the glomeruli (Germuth et al., 1968).

Heparin may be indicated in acute lupus nephritis for the following reasons. Firstly, in systemic lupus erythematosus the circulating antigen-antibody complexes together with the complement activate the clotting mechanism systemically. In addition the endothelial damage in glomerulonephritis can also promote coagulation by exposing collagen in the basement membrane and thus contributing to fibrin deposition (McKay, 1973). Secondly, widespread fibrin thrombi and fibrinoid deposits are seen in some cases (Lendrum et al., 1962; Paronetto and Koffler, 1965; McCluskey et al., 1966). In severe cases subendothelial deposits of fibrin are also seen. Thirdly, degradation products of fibrin are often present in large quantities in urine (Antoine and Ward, 1970; Cheatum et al., 1973) and are higher in the renal vein than in the systemic circulation (Conte et al., 1973 a). Heparin can prevent fibrin deposition and thrombotic obstruction of small vessels through its antithrombin activity, increasing the plasma C3 concentration in patients with systemic lupus erythematosus (Roth, 1965; Cade et al., 1973). It can also inhibit the action of antibodies (Roth, 1965) and neutralize serological reactions in lupus (Conte et al., 1973 b).

The results of heparin treatment in chronic lupus glomerulonephritis have been encouraging (Herdman et al., 1970; Cade et al., 1973). Moreover, improvement in renal function has been reported in three cases of acute lupus with anuric renal failure treated with heparin only (Conte et al., 1973 b). Our experience confirms this. The renal biopsy specimens in our patients showed signs of intrarenal coagulation before treatment, renal function improved remarkably with treatment, and subsequent renal biopsy in two cases showed that fibrinoid material had disappeared from the small vessels and glomeruli. Improvement in renal function together with an apparent modification of the natural course of the disease is exceptional in cases treated with corticosteroid or cytostatic agents either singly or in combination. Though it is difficult to distinguish the effect of heparin from that of the prednisone when they are given simultaneously possibly the anticoagulant reverses the renal lesions while the corticosteroid suppresses the acute toxic symptoms of systemic lupus erythematosus.

We think that treatment of anuric renal failure associated with acute lupus with large doses of corticosteroid and heparin in anticoagulant doses may substantially improve the prognosis. This combination of drugs, though centainly not without risk, seems to us to be fully justified in such a catastrophic situation.

We are grateful to Dr. J. S. Cameron for critically reviewing the manuscript.

\section{References}

Agnello, V., Koffler, D., and Kunkel, H. G. (1973). Kidney International, 3,

Antoine, B., and Ward, P. D. (1970). Clinical and Experimental Immunology, 6,153 .

Baldwin, D. S., et al. (1970). Annals of Internal Medicine, 73, 929.

Bjørneboe, M., Fischel, E. E., and Stoerk, H. C. (1951). The fournal of Experimental Medicine, 93, 37.

Cade, R., et al. (1973). Nephron, 10, 37.

Cameron, J. S., et al. (1970). Lancet, 2, 846.

Cheatum, D. E., et al. (1973). Arthritis and Rheumatism, 16, 670.

Christian, C. L. (1969). The New England Fournal of Medicine, 280, 878.

Christian, C. L. (1969). The New England fournal of Medicine, 280, 878.

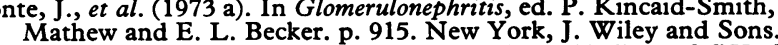

Conte, J., Mignon-Conte, M., and Suc, J. M. (1973 b). Fournal d'Urologie et de Nephrologie, 79, 332.

Dillard, M. G., et al. (1973). Nephron, 10, 273.

Donadio, J. V., et al. (1972). Annals of Internal Medicine, 77, 829.

Dubois, E. L. (1966). Lupus Erythematosus, p. 339. New York, McGraw-Hill

Germuth, F. G., jun., et al. (1968). The fohns Hopkins Medical fournal, 122, 137.

Germuth, F. G., jun. (1956). Pharmacological Review, 8, 1.

Herdman, R. C., Michael, A. F., and Good, R. A. (1970). Proceedings of the IV International Congress of Nephrology, ed. N. Alwali, F. Berglund, and IV International Congress of Nephrology, ed. N. Alwall, F. Bergl
B. Josephson. Stockholm 1969, p. 62, vol. III. Basel, Karger.

B. Josephson. Stockholm 1969, p. 62, vol. III. Basel,
Lange, K., et al. (1965). Arthritis and Rheumatism, 8, 244.

Lange, K., et al. (1965). Arthritis and Rheumatism, 8, 244.

Maher, J. F., and Schreiner, G. E. (1970). Archives of Internal Medicine, 125, 293.

McCluskey, R. T., et al. (1966). The New England fournal of Medicine, 274, 695.

McKay, D. G. (1973). In Glomerulonephritis, ed. P. Kincaid-Smith, T. H. Mathew, and E. L. Becker, p. 771. New York, J. Wiley and Sons.

Muehrcke, R. C. (1969). Acute Renal Failure. St. Louis, Mosby.

Paronetto, F., and Koffier, D. (1965). Fournal of Clinical Investigation, 44,

Pollak, V. E., and Mendoza, N. (1971). Medical Clinics of North America, 55, 1397.

Roth, K. L. (1965). Annals of Allergy, 23, 83.
Slama, R., Rueff, B., and Crosnier, J. (1962). Semaine des Hôpitaux de Paris,

Slama, R., Rueff, B., and Crosnier, J. (1962). Semaine des Hôpitaux

Zech, P., et al. (1972). fournal d'Urologie et de Nephrologie, 78, 987. 